\title{
ISLAM DI EROPA
}

\author{
Oleh: \\ Ali Geno Berutu \\ ali_geno@ymail.com \\ Sekolah Pascasarjana UIN Syarif Hidayatullah Jakarta
}

Antagonisme historis antara bagian barat dan timur Eropa tercermin sampai saat ini dalam perbedaan tradisi religius, sosial dan politik mereka. Perbedaan ini juga terlihat pada perubahan historis Islam di dunia Eropa. Pertumbuhan dan perkembangan disuatu bagian Eropa kerap kali mengiringi kemerosotan dan kejatuhan dibagian lainnya . Pada akhir abad pertengahan, kekuatan-kekuatan Kristen barat menaklukkan kembali wilayah-wilayah Muslim terakhir di Spanyol dan Laut Tengah. Selama abad ke-16 dan awal abad ke-17, mereka mencabuti sisa-sisa Islam terakhir dari barat. Sementara itu orang Turki tengah bersiap-siap menaklukkan Konstatinopel (1453) dan melakukan ekspansi kewilayah Eropa Tenggara, yaitu negara-negara Balkan sekarang. Akan tetapi tatkala keruntuhan Kesultanan Utsmaniyah, dominasi kekuasaan komunis, dan kebangkitan nasionalisme kontemporer mengakibatkan Islam Eropa Tenggara tertindas dan banyak warisan kuno dan prasarananya hancur, Eropa Barat malah membuka pintunya bagi arus migran dan pengungsi Muslim. Komunitas-komunitas Muslim signifikan kini ada di semua negara Eropa Barat.

\section{A. Fase dan Kelompok Dalam Sejarah Islam Eropa}

Sejarah pramoderen Islam di Eropa Barat terdiri atas dua bagian. Pertama , dari abad ke-8 hingga akhir abad ke-15, ada wilayah-wilayah yang dikuasi oleh Muslim, tempat posisi Islam sebagai mayoritas. Selain di Spanyol Muslim, inilah kondisi yang terjadi selama berbagai periode disejumlah pulau di Laut Tengah dan kantong-kantong kecil di Italia Selatan dan Prancis Selatan. Kedua, Sejarah Islam sebagai agama minoritas di Eropa Barat dimulai sekitar abad ke-19, ketika para penguasa Kristen khusnya disemanjung Liberia memutuskan untuk tidak lagi mengeksekusi tawanan Muslim, dan mulai menjual dan menggunakan mereka sebagai budak. Sejak pengujung abad ke-11, fenomena sosial budak-budak Muslim diwilayah Kristen semakin penting, khususnya disemenanjung Lberia, Italia, Prancis Selatan, Silsilia dan kepulauan Balearic. Sejarah yang mereka alami adalah sejarah kristenisasi dan asimilasi pesat dibawah tekanan masyarakat dan greja sekaligus. 
Bagi beberapa kerajaan Kristen disemenanjung Lberia, periode dari abad ke-12 hingga ke-16 merupakan kekecualian pola ini. Ketika Wilayahwilayah Spanyol Muslim ditaklukkan kembali oleh raja-raja Kristen, Komunitas-komunitas Muslim lokal mendapat kebebasan dan perlindungan dan perlindungan agama meskipun diprotes oleh greja Katolik. Akan tetapi setelah kejatuhan Granada (1492), Komunitas-komunitas ini dibaptis secara paksa dan akhirnya pada awal abad ke-17 dengan dicap kaum sesat, mereka akhirnya diusir dan sebagaian besar pergi ke Afrika Utara. Akan tetapi hal ini tidak mengakhiri fenomena sosial para budak Muslim. Keberadaan mereka dinegara-negara Eropa disekitar Laut Tengah terdokumentasi tanpa terputus hingga abad ke-19. Periode pencerahan yang diikuti Revolusi Prancis, dimaklumkannya kebebasan beragama sebagai hak asasi manusia universal dan dihapusnya perbudakan, menciptakan kondisi-kondisi yang amat diperlukan oleh moderen oleh Islam Eropa Barat.

Pada akhir abad ke-20, terdapat kurang lebih 18 juta Muslim di Eropa, hampir 9 juta masing-masing di Eropa barat dan Timur. Beberpa ribu Muslim hidup di Polandia dan Finlandia. Kaum Muslim Polandia adalah keturunan migran Tartar dan Krim yang tiba di negara ini pada abad ke-14 dan ke-15, serta abad ke-17 dan ke-18. Kaum Muslim Finlandia terdiri dari orang-orang yang berasal dari Turki-Tartar dari wilayah Volga dan Idel Ural yang bagian besar tiba setelah Revolusi Komunis 1917. Kaum Muslim di Eropa sebagian besar berada dinegara-negara Balkan. Mereka adalah keturunan dari berbagai kelompok yang memeluk Islam ketika Utsmaniyah berkuasa dan juga kelompok-kelompok Muslim asal non-Eropa, khususnya Turki. Banyak dari kelompok-kelompok ini terdiri atas semua tingkat sosial seperti, elit religius, intlektual, pedagang dan seni. Akan tetapi, di Eropa Barat Islam memperlihatkan keragaman sosial yang jauh berkurang. Pada dasarnya Islam masih merupakan agama kaum migran yang kebanyakan merupakan pekerja yang kurang trampil, pedagang kecil dan pedangan rendah.

Warga setempat yang menjadi Muslim ada disetiap negara Eropa Barat, tetapi jumlahnya sangat terbatas, yang menonjol adalah wanita yang menikah dengan pria Muslim, yang sesungguhnya mempelopori berdirnya organisasiorganisasi wanita Muslim yang menarik anggota dari seluruh kelompak etnis Muslim. Yang pria jumlahnya jauh lebih sedikit meskipun berperan penting dalam proses negosiasi dan komunikasi antar budaya antar kelompok Muslim disatu pihak serta masyarakat dan Pemerintah Eropa disisi lainnya. Sebagian dari mereka terkenal sebagai sarjana dan penulis, baik di dunia Muslim maupun Barat. 
Para migran Muslim di Eropa Barat dapat dibagi menjadi tiga kategori. Pertama, terdiri dari penduduk yang berasal dari bekas jajahan. Diantaranya adalah kelompok-kelompok yang bekerjasama dengan tentara penjajah Eropa dan lebih suka meninggalkan negara mereka ketika penjajahan berakhir. Kedua, Muslim terdiri sebagian besar atas pekerja yang tidak terampil beserta keluarga mereka. Mereka berasal dari negara-negara sekitar Laut Tengah, dari Anak Benua Indo-Pakistan, dan juga dari negara-negara Muslim lain di Timur Dekat dan Jauh. Di Prancis dan Inggris, proses migrasi ini dimulai sebelum Perang Dunia 11, dinegara-negara lain sebagian besar terjadi antara akhir 1960-an dan 1970-an. Khususnya sejak akhir 1970-an, dimulai proses reuni keluarga basis bagi institusionalisasi infrastruktur religius.

Kelompok-kelompok asal etnis atau geografis tertentu membentuk mayoritas dari kalangan penduduk Muslim. Inilah terjadi pada para migran dari wilayah Maghribi dan Afrika Barat di Prancis, Spanyol, Italia dan Belgia; pada orang Turki di Jerman dan Belanda ; dan pada orang Muslim dari Anak Benua Indo-Pakistan di Inggris. Dibandingkan dengan masyarakat-masyarakat tempat mereka hidup, mobilitas sosial ke atas dikalangan generasi kedua dan ketiga kelompok-kelompok ini tetap sangat terbatas. Persentase pengangguran diantara mereka lebih tinggi dibandingka dengan kalangan-kalangan kelompok asli setempat.

Arus migrasi Muslim terdiri atas pengungsi politik dari berbagai negara Muslim. Diantara mereka persentase yang mengenyam berbagai bentuk pendidiksn tinggi (nonreligius) seperti universitas angkanya tinggi. Banyak diantara diantara mereka ini berpandangan sekuler, dan mereka sejauh ini tidak memberikan kepemimpinan yang khusus religius kepada komunitaskomunitas Muslim. Namun mereka berperan penting dalam aktivitas budaya dan sosial politi yang bersifat lebih umum.

\section{B. Infarstruktur Religius}

Berbeda dengan infrastruktur religius mapan kaum Muslim di Eropa Tenggara, sejarah kontemporer Islam di Eropa Barat memperlihatkan banyak contoh komunitas-komunitas setempat yang semula bertemu di aula shalat, kemudian mendirikan masjid dan mengangkat imam. Pada awalnya, kelompok-kelompok Muslim ini acap kali menyewa tempat selama jangka waktu tertentu untuk beribadah. Kemudian ditemukan solusi -solusi lebih permanen. Pada tahap awal non-Muslim, khususnya para anggota gereja, berperan menonjol dalam prakarsa instutionalisme agama. Pada tahap kedua, prakarsa sebagian besar diambil oleh pemimpin informal komunitas 
bersangkutan. Akhirnya masjid berdiri berkat kelompok-kelompok yang berafiliasi dengan organisasi Islam pada tingkat Nasional atau Internasional.

Secara umum, di Eropa Barat masjid didirikan atas dasar monoetnis dan monosekte. Dengan pengecualian yang jarang, tempat-tempat ibadah multietnis dan multisekte berada dikota-kota kecil atau desa-desa yang masjid atau aula shalatnya hanya ada satu. Dikota-kota yang memiliki dua masjid atau aula shalat, biasanya ada kelompok-kelompok Muslim. Di komunitas-komunitas yang lebih besar, bisa terjadi ada kelompok-kelompok religius dalam satu kelompok etnis. Hal ini umumnya terlihat dikota-kota yang memiliki tiga masjid atau lebih. Sejajar dengan perkembangan sebelumnya, meningkat pulalah aspek-aspek fungsianal dari lembagalembaga keagamaan setempat. Pada awalnya fungsi bentuk pelembagaan Islam ini adalah memperhatikan kebutuhan layanan keagamaan. Pendirian tempat ibadah-ibadah ini merupakan tempat terbesar kaum Muslim bertemu untuk shalat, berarti menciptakan ruang dan jaringan sosial berdasarkan identitas religius bersama . Dalam banyak kasus pengajaran, pengajaran keagamaan tingkat awal yang disediakan oleh komunitas diberikan oleh relawan yang memenuhi syarat. Akan tetapi ccara terbaik untuk memenuhi kebutuhan ini adalah mengankat iman yang selain bertugas mengimami shalat juga sebagai pendidik bagi anak-anak. Masjid sebagai pusat pendidikan Islam terpenting di Eropa Barat, diperkirakan $15 \%$ dari semua anak-anak berlatar belakang Muslim menerima pendidikan keagamaan secara teratur, peran serupa dimainkan oleh masjid-masjid di Eropa Tenggara (kecuali Yunani) ; selama periode Komunis tidak ada ruang bagi Sekolah Dasar Islam yang diakui oleh negara.

Peningkatan komunitas Islam yang dirangsang oleh masjid meningkatkan peran penting mereka. Di negara-negara Muslim sendiri, banyak lembaga yang peran kulturalnya terpisah dari masjid, akan tetapi lembaga-lembaga seperti ini tidak terdapat dinegara-negara tuan rumah (Eropa Barat), dengan demikian, pemanfaatan masjid-masjid di Eropa Barat untuk mengemban sebagai an fungsi-fungsi infrastruktur al ini, merupakan pemecahan konstruktif karena berarti memberikan dukungan material lebih lanjut bagi pemeliharaan masjid dan pemeliharaan kehidupan komunitas Muslim itu sendiri. Hal ini memunculkan berbagai jenis kegiatan, antara lain dibidang pendidikan, olahraga, dan rekreasi, serta memberikan alternatif pola tingkah laku islami kepada generasi muda.

Akibatnya, bangunan masjid di Eropa Barat dipakai untuk bermacam acara bernuansa keagamaan yang biasanya tidak diselenggarakan didalam atau sekitar bangunan masjid di Dunia Muslim sendiri, seperti resepsi perkawinan, khitan, dan upacar berkabung. Sementara itu disebelah 
bangunan masjid terdapat toko-toko yang dimiliki oleh organisasi Muslim yang menjual benda-benda religius (seperti buku) serta produk-produk dari negara-negara asal dan memperluas basis sosial serta finansial kehidupan komunitas yang berpusat diseputar masjid. Sebagian besar masjid dikelola oleh pengurus. Para anggota dewan biasanya mengurusi kepentingan keuangan dan pemeliharaan masjid, jika tidak dibuat ketentuan khusus oleh bersama pemerintah negara asal, imam masjid diangkat oleh dewan, tugas dewan mencakup kedalam dan keluar, akan tetapi tugas imam terutama kedalam dan khusnya berhubungan dengan pengetahuan dan penerapan nilainilai Islam. Anggota dewan harus mampu mengelola masjid dan berkomunikasi serta bernegosiasi dengan masyarakat non-Muslim disekitarnya, untuk itu imam harus fasih berbahasa setempat, mengetahui dan mengerti hukum dan adat sosialnya.

Dengan tidak adanya perasaan sosial dari negara asal (keluarga, kenalan dsb), fungsi imam komunitas masjid amat meningkat di Eropa Barat. Tugas imam antara lain, memberikan bimbingan spritual dan peduli sosial, seperti mengajak anggota komunitas di rumah sakit dan penjara. Banyak kesamaan yang pening antara imam di Eropa dengan tugas pastor atau rabi. Konsekuensi logisnya, pemerintah dan pengadilan juga cenderung mengidentifikasi imam sebagai ulama yang mesti sama diperlakukan seperti pendeta Kristen dan Yahudi. Negara-negara yang resmi mengakui Islam seperti Belgia dan Spanyol yang mengesahkan pandangan ini secara eksplisit, dinegara-negara lain sudut pandang yang sama diungkapkan secara implisit, dalam yurisprudensi dan kebijakan pemerintah. Di Belanda Mahkamah Agung mengeluarkan putusan resmi bahwa secara yuridis pastor, rabi, imam, pendeta Hindu dan pemimpin spritual humanistik disertakan.

Disemua negara Eropa Barat, kaum Muslim semakin menyadari perlunya mendirikan pusat pendidikan sendiri untuk pelatihan imam. Proses ini dirancang oleh diskusi publik dan kebijakan pemerintah yang menghargai pendirian sarana-sarana seperti itu di negara-negara Eropa Barat. Selain persyaratan teologis yang ketat, tantangan baru pendidikan datang dari pospos yang sebelumnya tidak pernah ada bagi imam yang muncul dikalangan tentara, rumah sakit, dan penjara di Eropa Barat yang setarap dengan pendeta, pastor dan rabi yang diangkat oleh negara yang sudah bekerja dilembaga-lembaga itu. Jelas imam kategori baru ini membutuhkan bentukbentuk pelatihan tambahan agar ia dapat menangani tuga non-tradisional. Berdirinya sekolah Teologi Islam tidak diragukan lagi merupakan suatu momentum historis besar dalam sejarah Islam Eropa Barat, namun sejumlah rintangan menghadang realisasinya, yang paling menonjol adalah keragaman organisasi-organisasi Islam yang menyulitkan koordinasi dalam 
menggerakkan berbagai prakarsa dalam bersekala kecil yang sudah ada diberbagai negara. Infrastruktur religius Islam di Eropa Tenggara misalnya di Bosnia Herzegovina, imam dan ulama di didik di beberapa madrasah dan Fakultas Teologi di Sarajevo.

Di tingkat nasional dan itenasional, banyak ragam organisasi Islam yang saling bersaing untuk bisa berpengaruh di komunitas masjid setempat. Pada tahun 1970-an, upaya-upaya pertama untuk menciptakan struktur payung bagi masjid lokal, diantaranya adalah organisasi yang mewakili arus keyakinan yang berbeda dengan doktrin resmi Islam yang dipromosikan oleh pemerintah dinegara asal. Prakarsa ini ditiadakan oleh kegiatan pemerintah non-Eropa bersangkutan, yang mulai membangun jaringan komunitas masjidnya sendiri dikalangan warganya di negara-negara Eropa Barat. Contoh jelas pola ini terdapat dikalangan organisasi-organisasi Islam Turki.

Sebagai reaksi terhadap pesatnya perkembangan gerakan-gerakan keagamaan independen dan oposisional, seperi Suleymanlis, Milli Gorus dan Nursis, presidium urusan agama pemerintah Tuurki (biasanya disebut Diyanet) mengembangkan kebijakan untuk mendorong berdirinya infrastruktur religius bagi kaum Muslim Turki di Eropa Barat yang langsung di awasinya. Kebijakan ini antara lain, berupa pembangunan masjid dan pengangkatan imam serta guru agama yang dididik disalah satu perguruan tinggi atau Fakultas Turki. Para imam ini yang berstatus sebagai pegawai negeri sipil Turki, kebijakan ini juga mengangkat atase agama dengan status mufti untuk kedutaan besar Turki. Divisi-divisi organisasi serupa, akibat persaingan antar kelompok religius politik oposisional di satu pihak, dan pemerintah negara asal dipihak lain, juga terjadi di kalangan kaum Muslim lain, seperti pemerintah Tunisia, cenderung tidak melakukan campur tangan langsung dalam kehidupan beragama (mantan) warganya di Eropa Barat. Sesungguhnya Eropa Barat telah menjadi tempat berlindung untuk secara leluasa mengorganisasi gerakan organisasi-organisasi oposisi Islam. Tulisan pemimpin oposisi Maroko, Abd Al-Salam Yasin, misalnya yang dilarang di Maroko beredar dikalangan komunitas Maroko di Eropa Barat.

Selain itu, organisasi-organisasi internasional, seperti Dunia Muslim, yang di dukung oleh pemerintah negara-negara Muslim, berhasil mendirikan Pusat Islam di berbagai negara di Eropa Barat, seperti Brussel, Madrid dan Roma. Pusat-pusat ini bertujuan mengendalikan kehidupan religius Islam di Eropa Barat, dan biasanya di urus oleh wakil diplomatik negara-negara Muslim, dibawah pengaruh dominan Arab Saudi. Ini menambah kompleksitas pesaingan dan konflik yang masih terus mewarnai hubungan antar organisasi payung Islam pada tingkat nasional. 


\section{Agama dan Negara}

Saat ini semua negara Eropa mengklaim demokratis dan menghormati prinsip dasar kebebasan beragama meskipun ada perbedaan hubungan antar agama dan negara, yang diabadikan dalam konstitusi masing-masing dan diterapkan dalam kehidupan mereka, prinsip ini berlaku untuk segenap warga dan penduduk, temasuk kaum Muslim, secara individual maupun dalam bentuk organisasi keagamaan mereka. Prinsip konstitusional tentang kebebasan beragama di tarik oleh berbagai batas hukum yang membentuk Islam, mengikuti pola gereja dan sinagog di Eropa, menjadi lembaga religius yang terutama berfokus dibidang-bidang tertentu kehiidupan sosial. Bidangbidang ini berupa pengajaran moral dan agama, pelaksanaan ritual dan hari raya, pengorganisasian pendidikan dan pengetahuan keagamaan, serta penguatan berbagai kehiupan komunitas berbasis agama. Di bidang kehidupan sosial lainnya, yang berlaku tatanan publik dan monopoli negara. Kecuali Yunani, tempat Hukum Keluarga Islam dihormati sejak perjanjian Lausanne 1923 dan tempat gereja Ortodoks Yunani masih berperan dominan, dewasa ini tidak ada negara Eropa yang mengenal sistem kemajemukan hukum yang berdasarkan agama warga negara.

Tentu saja hal ini tidak berarti bahwa prinsip-prinsip hukum keluarga Islam tidak bernilai bagi keluarga Muslim di negara-negara Eropa. Sebaliknya seperti pemeluk agama-agama lain, kaum Muslim bebas menaatinya, secara sukarela dan dengan mmenghormati semestinya tatanan yuridis yang ada. Meraka bahkan dapat menciptakan pengadilan agama sendiri untuk menyelesaikan perselisihan internal mengenai semua masalah, seperti perkawinan, perceraian dan waris. Penciptaan pengadilan syariat informal seperti itu yang dapat disamakan dengan pengadilan rabi Yahudi, telah berlangsung di beberapa nnegara Eropa Barat, akan tetapi keputusa pengadilan seperti itu tidak mendapat validitas publik.

Penafsiran terhadap prinsip kebebasan beragama berbeda dari satu negara ke negara lain. Perbedaan ini berhubungan erat dengan kompleksitas sejarah politik dan budaya setiap negara. Penyemblihan hewan menurut ajaran Islam (dan Yahudi), misalnya diperbolehkannya di banyak negara (dengan persyaratan khusus yang ditetapkan undang-undang), tetapi dilarang disebagian negara, seperti Swiss dan Swedia. Perselisihan mengenai berjilbab di sekolah umum, lagi-lagi berakhir berbeda. Di sebagian negara seperti Belanda, ekspresi perilaku religius Islam di hormati. Akan tetapi, di sebagian lain, seperti Belgia dan Prancis, keputusan membolehkan berjilbab 
berada ditangan kepala sekolah. Selama kasus Salman Rushdie, undangundang penghujatan yang ada tanpaknya hanya berlaku pada agama-agama mapan di Inggris, tetapi di Belanda berlaku pula pada Islam. Sikap terhadap hak berhari raya agama masih beragam meskipun yurisprudensi cendrung mengakui hak pekerja untuk berlibur satu atau beberapa hari lebih untuk maksud ini, asalkan perusahaan diberi tahu sebelumnya dan tidak membawa kerugian serius bagi kepentingan perusahaan. Putusan komisi Hak Asasi Manusia Eropa menetapkan bahawa pekerja Muslim berhak menunikan shalat jumat jika ia memberi tahu perusahaan ketika ia bekerja bahwa penuaian kewajiban keagamaan ini berbarengan dengan kewajibab sebagai pekerja.

Aspek penting dalam hubungan antara agama dan negara adalah sikap dominan di setiap negara terhadap nilai sosial agama. Hal ini berbeda tidak ada antara negara, tetapi juga di dalam setiap negara dan bahkan dari satu periode ke periode lain serta kalangan di berbgai partai politik. Bahkan beberapa negara secara resmi menganggap sangat pentingnya agama dalam memelihara norma dan nilai masyarakat. Jika syarat-syarat tertentu yang ditetapkan hukum dipenuhi oleh organisasi keagamaan, negara-negara ini mau bekerja sama dengannya dan bahkan mensubsidi. Negara-negara lain cenderung menekankan sifat pribadi agama, karakter sekuler masyarakat mereka, dan akibatnya enggan mendanai organisasi keagamaan. Meskipun demikian, bisa saja mensubsidi agama secara tak langsung, misalnya tidak mengenakan pajak pada sumbangan atas nama keagamaan, suatu praktik di banyak negara Eropa.

Perbedaan-perbedaan ini juga terkait dengan beragam tradisi konstitusional Eropa menggenai hubungan antara agama dan negara. Kecuali Kota Vatikan, tradisi-tradisi seperti ini dapat di klasifikasikan secara luas berdasarkan model penyatuan dan pemisahan. Model penyatuan melibatkan hubungan yuridis langsung anatara agama dan negara. Model ini dapat dibagi menjadi tiga tipe. Pertama, beberapa negara mengakui secara resmi komunitas-komunitas religius. Ini menunjukkan bahwa mereka mempertimbangkan secara resmi keberadaan komunitas-komunitas itu dan masyarakat pada umumnya (contoh: Spanyol, Belgia dan Jerman). Tipe kedua adalah keberadaan satu agama resmi negara yang di dalamnya konstitusi menghormati kebebasan beragama dan hak agama-agama lain untuk diperlakukan sama. Ini yang terjadi, misalnya di Denmark, Swedia dan Inggris. Tipe ketiga adalah perlakuan istimewa resmi terhadap satu komunitas religius. Ini terjadi di Yunani dan biasanya disebut dengan istilah "konfesionalisme". 
Selain itu terdapat pula model pemisahan antara agama dan negara, yang menekankan netralitas negara, persamaan semua agama dan falsafah hidup, serta pada tingkat yang beragam, karakter sekuler segenap ruang publik masyarakat. Model ini dipraktekkan di Prancis dan Belanda. Akan tetapi dalam penerapannya, negara-negara ini banyak memperlihatkan perbedaan secara berarti, misalnya atas dasar "sistem pilarisasi" Belanda yang terkenal yang memberikan hak kepada setiap komunitas religius di Belanda, juga di tingkat lokal, untuk mmengembangkan dengan subsidi negara semua lembaga religius di bidang pendidikan dan sosial budaya, telah didirikan sekitar tiga puluh Sekolah Dasar Islam. Contoh ini menggambarkan arti terbatas berbagai teori konstitusional untuk menilai dengan benar kemungkinan nyata yang tersedia bagi kelompok-kelompok religius di setiap negara.

Konstitusi Spanyol mengungkapkan kesiapan negara untuk bekerja sama dengan gereja dan agama lain sepanjang di butuhkan untuk membuat hak warga negaranya menikmati kebebasan beragama menjadi nyata dan aktif. Untuk mendapatkan pengakuan yang diperlukan untuk mencapai persetujuan dalam bekerja sama, pihak-pihak yang terlibat harus mmmembuktikan berdasarkan inskrifsi dalam Daftar Entitas Religius resmi, setidak-tidaknaya jumlah tertentu penganut keyakinan. Para penganut agama Protestan, Yahudi dan Islam telah diserahi undang-undang ini, dan kesepakatan resmi antar negara dan penganut agama ini di tandatangani pada tahun 1992.

Comision Islamica de Espana (CIE) diakui sebagai perwakilan resmi kaum Muslim Spanyol, dipilih oleh dua pederasi yang tercantum dalam daftar Entitas Religius resmi, yang pada masa mendatang dapat ditambahai komunitas atau federasi lain. Kesepakatan telah mebuat daftar panjang subjek relevan, seperti undang-undang masjid dan aula shalat, perkuburan Islam dan aturan Islam berkenaan dengan makanan, ritus pemakaman, imam, serta pemimpin keagamaan lainnya. Ia juga mengatur hak-hak religius serdadu Muslim dan personel tentara Muslim dan tawanan serta pasien Muslim di rumah sakit. Orang tua dan anaknya dijamin haknya untuk mendapat pendidikan dasar dan menengah. Komisi Islam Spanyol (CIE) dan juga komunitas-komunitas yang terkait dengannya, dapat mendirikan dan mengelola pusat pendidikan dasar dan menengah, maupun universitas dan pusat informasi Islam sesuai dengan perundang-undangan umum mengenai masalah ini. Kesepakatan juga memberikan sejumlah privelese pajak kepada CIE dan komunnitas-komunits terkait. Ia juga mendefenisikan hak siswa Muslim dan pekerja Muslim untuk merayakan hari besar keagamaan, mematuhi ketentuan Ramadhan dan bershalat jumat setiap pekan. Akhirnya 
ia mengatakan bahwa CIE adalah satu-satunya otoritas di Spanyol yang memberikan tanda "halal" pada produk-produk makanan untuk menunjukkan bahwa produk-produk itu di siapkan menurut hukum Islam. Aturan makanan dalam Islam akan dihormati di lembaga pemasyarakatan, kawasan tentara, rumah sakit, dan sekolah bbagi Muslim yang meminta ini, hal ini juga terjadi pada jadwal Ramadhan.

Pemerintah Spanyol berperan aktif dalam membentuk lembaga perwakilan atas nama kaum Muslim di Spanyol. Namun, di Belgia yang mengakui Islam secara resmi pada tahun 1974 tidak demikian, untuk mmewujudkan bantuan keuangan, pada prinsipnya pemerintah Belgia siap memberikan kepada berbagai aktivitas religius Islam (seperti gaji imam, biaya masjid, pendirian Sekolah Islam, pendidikan keagamaan di sekolah publik, dsb). Komisi yang memiliki perwakilan harus ditetapkan undangundang. Komisi ini bertanggung jawab atas harta yang digunakan untuk ibadah dan sekali gus berfungsi sebagai perantara dengan pemmerintah nasional, ia harus dipilih ditingkat provinsi sesuai dengan praturan. Yang mengorganisasi pemilihan ini adalah Pusat Budaya Islam di Brussel (di danai oleh liga Dunia Muslim). Orang Belgia berhubungan dengan pusat ini untuk sementara sebagai wakil kaum Muslim Belgia sejak Islam di akui secara resmi. Akan tetapi, pemilihan yang berlangsung tidak di akui sehingga banyak tindakan potensial yang dapat meningkatkan infrastruktur religius Islam belgia tidak diterima sama sekali. Namun, guru pendidikan Islam di angkat di sekolah publik Belgia atas rekomendasi "Dewan Sementara Orang Bijak Untuk Mengorganisasi Pengkhidmatan Islam di Belgia" (Provisional Council of Wise Persons For The Oranizantion of The Islamic Cult in Belgium) yang dibentuk pada tahun 1990 di Brussel, yang lagi-lagi untuk sementara.

Dari sudut pandang umum, dapat disimpukan bahwa kaum Muslim belum sepenuhnya memanfaatkan peluang yang diberikan oleh beragam sistem hukum di negara-negara Eropa. Perelisihan mereka dan tidak adanya pemimpin berbobot merupakan faktor penting untuk menjelaskan hal ini. Akan tetapi, yang juga penting adalah sikap negatif terang-terangan yang ditujukan oleh banyak sektor masyarakat Eropa terhadap minoritas etnis ditengah-tengah mereka umumnya dan pemeluk agama Islam khususnya. Gerakan-gerakan politik ekstrimis beridiologi rasis bermunculan di Eropa pada beberapa tahun baru lalu dan mampu memperoleh banyak suara dalam pemilihan lokal dan nasional. Penggaruh mereka jelas tercermin dalam sikap tidak konsisten dari sebagian partai politik yang mapan. Tindakan-tindakan kekerasan terhadap harta dan jiwa kaum Muslim serta kelompok minoritas lainnya merupakan realitas yang menyedihkan. Kini hampir tak ada masjid 
atau aula shalat yang dibuka tanpa disertai dengan protes dari non-Muslim. Dan politisi yang membela hak-hak konstitusional kelompok minoritas beresiko kehilangan banyak dukungan pemilih. Kejadian-kejadian dramatis di Eropa Tenggara telah menimbulkan kekhawatiran akan kelangsungan hidup kebebasan, demokrasi dan persamaan dalam hubungannya dengan Islam di Eropa. 